Jurnal Paradigma Ekonomika Vol.16. No.3, Juli - September 2021 ISSN: 2085-1960 (print); 2684 -7868 (online)

\title{
Analsis determinan yang mempengaruhi perdagangan luar negeri Indonesa terhadap dua negara yang terlibat perang dagang Amerika Serikat VS China
}

\author{
Emilia*; Adi Bhakti; Candra Mustika \\ Prodi Ekonomi Pembangunan Fak. Ekonomi dan Bisnis Universitas Jambi \\ *E-mail korespondensi:emilia@unja.ac.id
}

\begin{abstract}
The purpose of this study is to analyze how Indonesia's exports and imports compared to the United States and China and to investigate how the exchange rate, labor force, and population influence Indonesia's imports from China and the United States. The results show that Indonesia's exports to the United States and Indonesia's exports to China are 2.02, while the average comparison of Indonesian imports from the United States and Indonesia's imports from China is 1.31. the average is more significant when compared to Indonesia's exports and imports with China. Based on the regression results, the exchange rate variable has a significant negative effect on Indonesia's exports and imports with the United States and China. The labor variable has a significant positive impact on Indonesia's exports and imports to the United States and China. In contrast, the population variable significantly affects Indonesia's exports to the United States. It does not substantially affect Indonesian imports from the United States and does not dramatically affect Indonesia's exports and imports with China.
\end{abstract}

Keywords: Import-export, Exchange rate, Labor, Total population

\begin{abstract}
Abstrak
Tujuan dari penelitian ini adalah untuk menganalisis bagaimana perbandingan ekspor dan impor Indonesia ke negara Amerika Serikat dan ke negara China serta untuk menganalis bagaimana pengaruh kurs, tenaga kerja dan jumlah penduduk terhadap impor Indonesia dari China dan Amerika Serikat. Hasil penelitian menunjukkan rata-rata perbandingan ekspor Indonesia ke Amerika Serikat dan ekspor Indonesia ke China adalah 2,02 sementara rata-rata perbandingan Impor Indonesia dari Amerika Serikat dan impor Indonesia dari China adalah 1,31 sehinga kesimpulannya ekspor dan impor Indonesia dengan Amerika Serikat secara rata-rata lebih besar jika dibandingkan dengan ekspor dan impor Indonesia dengan China. Berdasarkan hasil regresi variabel kurs berpengaruh negatif signifikan terhadap ekspor dan impor Indonesia dengan Amerika Serikat dan China, variabel tenaga kerja berpengaruh positif signifikan terhadap ekspor dan impor Indonesia ke Amerika Serikat dan China, sementara variabel jumlah penduduk berpengaruh positif signifikan terhadap ekspor Indonesia ke Amerika Serikat namun tidak berpengaruh signifikan terhadap impor Indonesia dari Amerika Serikat serta tidak berpengaruh signifikan ekspor dan impor Indonesia dengan China.
\end{abstract}

Kata kunci: Ekspor impor, Kurs, Tenaga kerja, Jumlah penduduk

\section{PENDAHULUAN}

Dalam neraca perdagangan Indonesia beberapa tahun terakhir menunjukkan bahwa Negara China dan Amerika Serikat merupakan mitra dalam perdagangan bagi Indonesia diantara data Asian development Bank (ADB ) Tahun 2018 menunjukkan negara tujuan ekspor Indonesia di dunia yang terbesar adalah Jepang dan China menempati urutan 
pertama dengan nilai ekspor pada tahun 2017 sebesar 23.049 Juta US Dollar sementara Amerika Serikat menempati urutan kedua dengan nilai ekspor 17.810 Juta US Dollar. Dan begitupun dengan impor diantara Negara yang paling banyak barang dan jasanya yang di impor oleh Indonesia adalah Negara China menempati urutan pertama dengan total impor sebesar 34.521 Juta US Dollar sementara Amerika Serikat menempati urutan ke enam dengan total nilai impornya 8.216 Juta US Dollar.

Saat ini perekonomian dunia sedang bergejolak diantaranya adalah karena terjadinya perang dagang yang melibatkan dua Negara besar raksasa ekonomi dunia tersebut yakni Amerika Serikat melawan China, peristiwa perang dagang tersebut secara langsung atau tidak langsung dan sedikit banyak pasti akan berdampak terhadap Negara lain yang juga melakukan perdagangan terhadap kedua Negara tersebut dan Indonesia pun termasuk merupakan mitra dagang bagi kedua Negara tersebut sehingga perlu upaya pencegahan dan antisipasi agar dampak perang dagang tersebut tidak mengganggu perekonomian Indonesia khususnya ekspor Indonesia ke kedua Negara yang terlibat perang dagang tersebut.

Smith dalam Ekonomi Internasional haryadi 2007 dan Nopirin 2003 dengan teori perdagangan internasionalnya yang dikenal dengan teori keunggulan mutlak menyatakan Negara-negara melakukan spesialisasi dalam memproduksi barang-barang yang memiliki keuntungan mutlak. Teori ini lebih mendasarkan pada besaran variabel riil bukan moneter dalam artian teori ini sesuatu barang diukur dengan banyaknya tenaga kerja yang dialokasikan dalam memproduksi barang. Sehingga ukuran biaya yang digunakan adalah jumlah alokasi tenaga kerja yang digunakan tenaga kerja yang banyak otomatis biaya upah yang digunakan juga mahal dan akibatnya harga mahal sehingga kesimpulan teori ini suatu Negara memiliki keunggulan mutlak jika Negara tersebut mampu memproduksi barang secara efisien dari Negara lain namun teori ini gagal jika keunggulan mutlak hanya dimiliki oleh satu Negara karena itu tokoh klasik lainnya David Ricardo dan J.S. Mill menggunakan keuntungan berbanding dalam mngetahui spesialisasi suatu Negara sehingga walaupun Negara tersebut tidak memiliki keunggulan mutlak namun Negara tersebut masih bisa berdagang dengan mengetahui keunggulan perbandingan komoditas barang nya. Salah satu teori modern dalam perdagangan internasional yang terkenal adalah teori Hecksher dan Ohlin atau lebih dikenal Model H-O inti teori ini menyatakan ada dua faktor produksi yang dimiliki oleh suatu Negara yakni tenaga kerja dan Modal, Negara yang memiliki faktor produksi melimpah akan memproduksi barang sesuai dengan faktor produksi yang melimpah dinegara tersebut, jika disuatu Negara yang melimpah adalah tenaga kerja maka barang yang diproduksi adalah barang bersifat padat karya atau labour intensif dan jika yang melimpah adalah modal maka barang yang diproduksi adalah barang yang bersifat padat modal atau Capital intensif.

Ni Putu Ayuning Wulan Pradnyani dkk 2018 (Institut pertanian bogor IPB) dalam Journal of Agribusiness and Rural Development Research UMY Yogyakarta, dengan judul penelitian 'Pengaruh variabel makro ekonomi terhadap penyaluran ekspor impor dengan metode pembayaran Letter of credit menemukan hasil dengan variabel makro ekonominya yakni kurs, inflasi dan Bank Indonesia, semua variabel makro tersebut pengaruhnya signifikan terhadap ekspor LC sementara hanya inflasi yang tidak berpengaruh terhadap impor LC.

Darman (Binus University) dalam jurnal manajemen Indonesia tahun 2017 menemukan bahwa variabel ekspor berpengaruh positif signifikan terhadap PDB sementara Impor dan indeks harga konsumen berpengaruh negative signifikan terhadap 
PDB. Ria yani fatmawati Universitas negeri malang dalam Jurnal JESP 2015 dengan penelitiannya mencoba menganalisis pengaruh perdagangan luar negeri dan hutang terhadap PDB hasilnya ekspor berpengaruh positif signifikan terhadap PDB , Impor berpengaruh negatif signifikan terhadap PDB ,Hutang luar negeri tidak berpengaruh signifikan Yusuf dan widyastuti ( dalam Jurnal manajemen agribisnis IPB 2007) menganalisis pengaruh ekspor impor komoditas pangan dan liberalisasi perdagangan terhadap neraca perdagangan Indonesia hasilnya semua variabel tersebut berpengaruh negatif signifikan terhadap neraca perdagangan.

Yeti andriani dan andre (Universitas andalas dalam Journal international studies 2017) dengan penelitian implikasi perjanjian kemitraan ekonomi komprehensif Indonesia Australia terhadap perdagangan luar negeri menemukan bahwa kerjasama tersebut dapat memfasilitasi perdagangan luar negeri Indonesia dan Australia. Kuswantoro dan Gita Rosianawati tahun 2016 dengan penelitiannya berjudul Analisis pengaruh PDB riil,Cadangan devisa dan Nilai tukar rupiah terhadap impor non migas Indonesia dalam Jurnal Ekonomi Qu FEB Universitas Sultan ageng tirtayasa menemukan hasil bahwa dalam jangka pendek nilai tukar rupiah dan PDB berpengaruh positif dan signifikan sementara dalam jangka panjang ketiganya berpengaruh positif signifikan terahdap impor non migas Indonesia.

\section{METODE}

Untuk menjawab permasalahan pertama dan kedua dalam penelitian ini digunakan metode analisis deskriptif dan kuantitatif Untuk menjawab permasalahan pertama yakni menganalisis perbandingan ekspor dan impor Indonesia ke dua negara yang terlibat perang dagang yakni Amerika Serikat dan China digunakan rumus perbandingan yakni :

Perbandingan ekspor Indonesia ke Amerika Serikat dan China $=\mathrm{XA} / \mathrm{XC}$

Perbandingan impor Indonesia ke Amerika Serikat dan China = MA/MC

Keterangan:

$\mathrm{XA}=$ Ekspor Indonesia ke Amerika Serikat

$\mathrm{XC}=$ Ekspor Indonesia ke China

$\mathrm{MA}=$ Impor Indonesia ke Amerika Serikat

$\mathrm{MC}=$ Impor Indonesia ke China

Untuk menjawab masalah kedua pengaruh kurs,tenaga kerja dan jumlah penduduk terhadap ekspor Indonesia ke China dan Amerika Serikat digunakan model regresi berganda yakni sebgaai berikut :

$$
\begin{aligned}
& \mathrm{Xc}=\boldsymbol{\beta}_{0}+\beta_{1} \mathbf{K}+\beta_{2} \mathrm{TK}+\boldsymbol{\beta}_{2} \mathrm{JP}+\varepsilon \\
& \mathrm{Xa}=\boldsymbol{\beta}_{0}+\boldsymbol{\beta}_{1} \mathrm{~K}+\boldsymbol{\beta}_{2} \mathrm{TK}+\boldsymbol{\beta}_{2} \mathrm{JP}+\varepsilon
\end{aligned}
$$

Untuk menjawab permasalahan kedua dalam penelitian ini yakni menganalisis pengaruh kurs,tenaga kerja dan jumlah penduduk terhadap impor Indonesia ke China dan Amerika Serikat digunakan model regresi berganda yakni sebgaai berikut :

$$
\begin{aligned}
& \mathrm{Mc}=\boldsymbol{\beta}_{0}+\boldsymbol{\beta}_{1} \mathbf{K}+\boldsymbol{\beta}_{2} \mathbf{T K}+\boldsymbol{\beta}_{2} \mathbf{J P}+\varepsilon \\
& \mathrm{Ma}=\boldsymbol{\beta}_{0}+\boldsymbol{\beta}_{1} \mathbf{K}+\boldsymbol{\beta}_{2} \mathbf{T K}+\boldsymbol{\beta}_{2} \mathbf{J P}+\varepsilon
\end{aligned}
$$


Dimana:

Xc :Ekspor ke China

$\mathrm{Xa}$ :Ekspor ke Amerika Serikat

Ma :Impor ke Amerika serikat

Mc :Impor ke China

TK :Tenaga kerja

K :Kurs US dollar terhadap rupiah

JP :Jumlah penduduk

$\beta_{0} \quad$ : Konstanta

$\beta_{1,2,3}$ : Koefisien regresi variabel independen

$\varepsilon \quad:$ Error term

\section{HASIL DAN PEMBAHASAN}

\section{Perbandingan ekspor dan impor Indonesia ke Amerika Serikat dan China}

Untuk mengetahui perbandingan ekspor Indonesia ke Amerika Serikat dan ekspor Indonesia ke China serta impor Indonesia dari Amerika Serikat dan impor Indonesia dari China dapat dilhat pada Gambar 1 berikut ini :

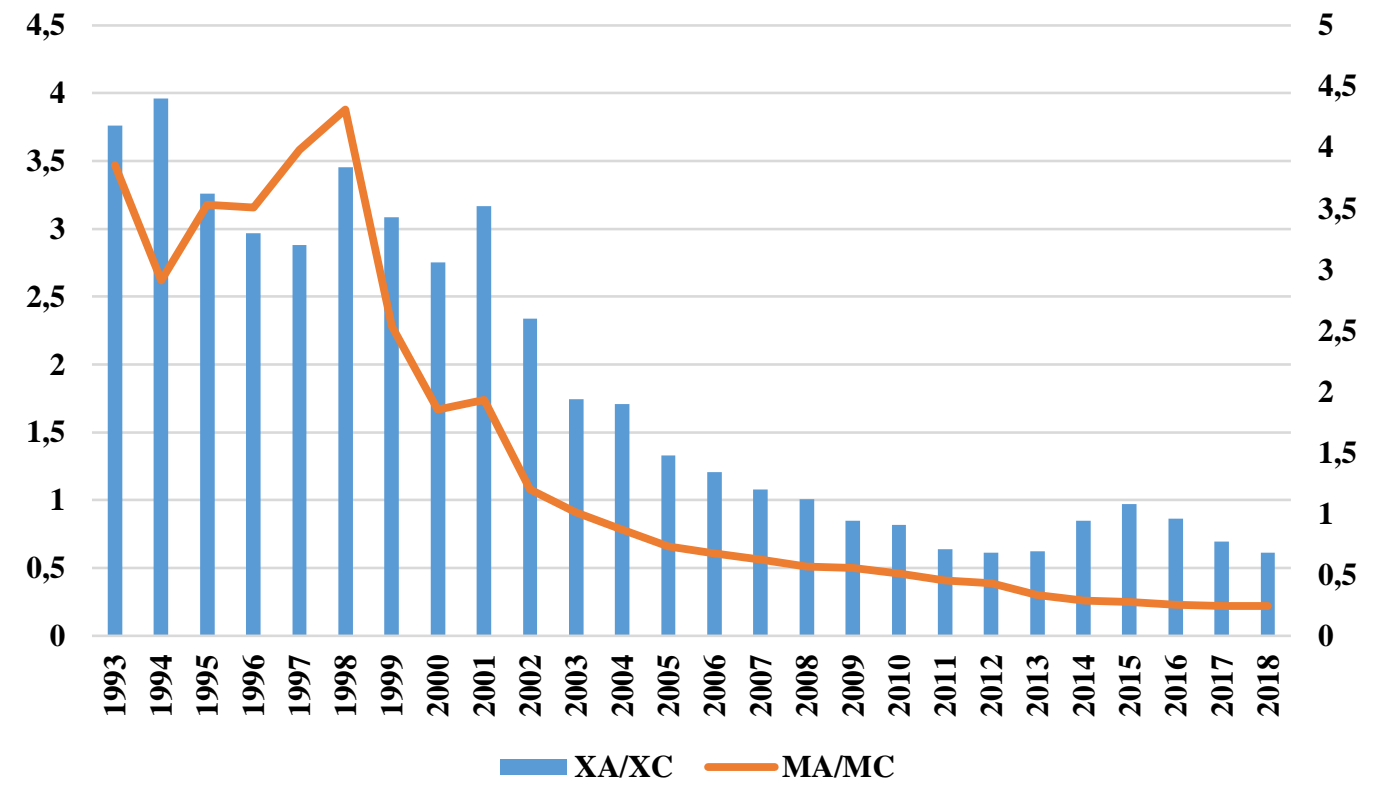

Sumber : $A D B, 2020$ (diolah)

Gambar 1. Perbandingan ekspor dan impor Indonesia ke Amerika Serikat dan ekspor dan impor Indonesia ke China

Berdasarkan Gambar 1. terlihat bahwa pada aeal periode ekspor dan impor Indonesia terhadap Amerika Serikat lebih besar jika dibandingkan dengan ekspor dan impor Indonesia terhadap China hal ini dapat dilihat dari angka perbandingannya yang melebihi dari satu namun jika dilihat beberapa tahun kemudian setelah tahun 2000 an terlihat bahwa angka perbandingan tersebut makin lama makin kecil artinya ekspor dan impor Indonesia terhadap Amerika Serikat cendrung turun atau sebaliknya ekspor impor Indonesia terhadap China mengalami peningkatan, namun secara rata-rata perbandingan ekspor Indonesia ke China dan Amerika Serikat sebesar 2,02 masih lebih dari satu dan impor Indonesia ke Amerika Serikat dan China rata-rata perbandingannya 1,31 atau 
masih lebh dari satu artinya secara rata-rata ekspor dan impor Indonesia terhadap Amerika Serikat lebih besar jika dibandingkan dengan ekspor dan impor Indonesia dengan China.

\section{Pengaruh kurs, tenaga kerja dan jumlah penduduk terhadap ekspor Indonesia ke Amerika Serikat}

Untuk mengetahui pengaruh kurs,tenaga kerja dan jumlah penduduk terhadap ekspor Indonesia ke Amerika Serikat dapat dilihat pada hasil regresi Tabel 1 berikut ini :

Tabel 1. Hasil regresi pengaruh kurs,tenaga kerja dan jumlah penduduk terhadap ekspor Indonesia ke Amerika Serikat

\begin{tabular}{lrccr}
\hline \multicolumn{1}{c}{ Variable } & Coefficient & Std. Error & t-Statistic & Prob. \\
\hline C & -33383.50 & 3834.365 & -8.706395 & 0.0000 \\
Kurs & -0.238949 & 0.084276 & -2.835300 & 0.0096 \\
\multicolumn{1}{c}{ Jumlahpenduduk } & 204.8074 & 65.06988 & 3.147499 & 0.0047 \\
Tk & 0.211426 & 0.050871 & 4.156077 & 0.0004 \\
R-squared & 0.968346 & Mean dependent var & 11106.58 \\
Adjusted R-squared & 0.964029 & S.D. dependent var & 4315.408 \\
S.E. of regression & 818.4586 & Akaike info criterion & 16.39336 \\
Sum squared resid & 14737237 & Schwarz criterion & 16.58691 \\
Log likelihood & -209.1137 & Hannan-Quinn criter. & 16.44910 \\
F-statistic & 224.3362 & Durbin-Watson stat & 1.902261 \\
Prob(F-statistic) & 0.000000 & & \\
\hline Sumber:Datad & & &
\end{tabular}

Sumber : Data diolah, 2021

\section{Hasil uji asumsi klasik :}

\section{Autokorelasi}

Untuk mengetahui terdapat autokorelasi atau tidak digunakan ujia LM Test dengan hasilnya sebagai berikut :

Tabel 2. Uji autokorelasi

\section{Breusch-Godfrey Serial Correlation LM Test:}

\begin{tabular}{llll}
\hline F-statistic & 0.393797 & Prob. F(2,20) & 0.6796 \\
Obs*R-squared & 0.985081 & Prob. Chi-Square(2) & 0.6111 \\
\hline
\end{tabular}

Sumber : Data diolah, 2021

Berdasarkan hasil tersebut terlihat bahwa nilai ObsRsquared 0,61 lebih besar dari alpha 5\% sehingga disimpulkan tidak terdapat autokorelasi.

\section{Heteroskedastis}

Untuk mengetahui terdapat heteroskedastis dilakukan uji LM tes dengan hasilnya sebagai berikut :

Tabel 3. Uji heteroskedastisitas

\begin{tabular}{lcll}
\hline Heteroskedasticity Test: Breusch-Pagan-Godfrey & \\
\hline F-statistic & 0.253539 & Prob. F(3,22) & 0.8580 \\
Obs*R-squared & 0.868871 & Prob. Chi-Square(3) & 0.8329 \\
Scaled explained SS & 0.677157 & Prob. Chi-Square(3) & 0.8786 \\
\hline
\end{tabular}

Sumber : Data diolah, 2021 
Berdasarkan hasil tersebut tidak terdapat gejala heteroskedastis nilai probabilitas ObsRsquare 0,83 besar dari alpha $5 \%$.

Multikolinearitas

Untuk melihat ada tidaknya multikolinearitas dapat dilihat pada nilai VIF

Tabel 4. Uji multikolinearitas

\begin{tabular}{cccc}
\hline & Coefficient & Uncentered & Centered \\
\hline Variable & Variance & VIF & VIF \\
C & 14702355 & 570.6461 & NA \\
Kurs & 0.007103 & 24.45031 & 3.416649 \\
Jumlah penduduk & 4234.090 & 2587.134 & 17.32706 \\
TK & 0.002588 & 1005.140 & 17.36616 \\
\hline
\end{tabular}

Sumber : Data diolah, 2021

Berdasarkan dari data diatas terlihat nilai VIF besar dari 10 maka memang terdapat gejala multikolineritas

\section{Hasil uji statistik}

\section{Uji F}

Berdasarkan nilai $\mathrm{F}$ hitung 224 dengan probabilitas mendekati nol maka disimpulkan secara bersama-sama variabel bebas Kurs,Jumlah penduduk dan tenaga kerja berpengaruh signifikan terhadap ekspor Indonesia ke amerika serikat.

\section{Uji t}

Untuk menguji statistik secara parsial pengaruh masing-masing variabel kurs,jumlah tenaga kerja dan jumlah penduduk terhadap ekspor Indonesia ke Amerika Serikat digunakan uji t statistik. Variabel kurs nilai t hitung $-2,83$ dengan probabilitas 0,0096 kecil dari alpha $1 \%$ artinya kurs berpengaruh signifikan terhadap ekspor Indonesia ke Amerika Serikat pada level 1\% Variabel jumlah penduduk dengan nilai t hitung 3,14 dengan probailitas 0,0047 kecil dari alpha $1 \%$ artinya secara parsial jumlah penduduk berpengaruh signifikan terhadap ekspor amerika serikat. Variabel tenaga kerja dengan nilai t hitung 4,15 dengan probabilitas 0,0004 kecil dari alpha 1\% sehingga disimpulkan tenaga kerja berpengaruh signifikan terhadap ekspor ke amerika serikat

\section{Koefisien determinasi}

Koefisien determinasi (R square) dengan nilai 0,96 artinya 96\% perubahan ekspor Indonesia ke Amerika Serikat dipengaruhi oleh variabel bebas dalam model sisanya $4 \%$ berada diluar model

\section{Interpretasi hasil regresi}

Berdasarkan hasil regresi diperoleh persamaan sebagai berikut :

\section{Ekspor ke Amerika Serikat = -33383-0,23Kurs+204JP+0.21TK+e}

Berdasarkan hasil uji signifikansi maka yang di interpretasikan dari hasil regresi yaitu : 1).Konstanta menunjukkan pada posisi semua variabel bebas bernilai nol maka nilai ekspor Indonesia ke Amerika Serikat -33383 Juta US Dolar. 2).Koefisien regresi kurs 
menunjukkan jika kurs meningkat atau terdeprisiasi 1 rupiah maka ekspor Indonesia ke Amerika Serikat dalam jangka panjang akan turun sebesar 0,23 juta us dolar. 3).Koefisien jumlah penduduk 204 menunjukkan jika terjadi kenaikan penduduk sebesar 1 juta jiwa maka ekspor Indonesia ke Amerika Serikat akan naik sebesar 204 juta us dollar. 4).Koefisien regresi tenaga kerja 0,21 artinya setiap kenaikan 1 juta jiwa tenaga kerja akan meningkatkan ekspor sebesar 0,21 Juta us dollar

\section{Implikasi hasil}

Berdasarkan hasil regresi diperoleh hasil ternyata kurs berpengaruh negatif dan signifikan terhadap ekspor Indonesia ke Amerika Serikat secara teoritis dalam jangka pendek hal ini mungkin berbeda dengan kenyataan karena seharusnya dengan terdepresiasinya rupiah harusnya ekspor meningkat karena harga barang ekspor Indonesia jadi lebih murah namun asumsi ini terjadi hanya dalam jangka pendek karena jika dalam jangka panjang kurs terdepresiasi akan menyebabkan harga barang modal yang sering diimpor Indonesia akan lebih mahal hal ini akan meningkatkan biaya produksi dan menyebabkan turunnya produksi termasuk untuk ekspor karena penelitian ini periode penelitiannya dalam jangka panjang maka asumsi tersebut telah terpenuhi sesuai dengan penjelasan ekonomi yang telah diuraikan tersebut.

Sementara hasil regresi lainnya menunjukkan jumlah penduduk berpengaruh positif signifikan terhadap ekspor Indonesia ke Amerika Serikat hal ini menunjukkan bahwa penduduk yang menurut teori klasik dianggap faktor produksi yang dapat meningkatkan output dengan meningkatnya output maka kebutuhan di dalam negeri dapat terpenuhi sehingga kelebihan produksi dapat di ekspor ke luar negeri. Dan ternyata hasil lainnya menunjukkan tenaga kerja ternyata berpengaruh signifikan dalam mempengaruhi ekspor Indonesia ke Amerika Serikat hal ini mengindikasikan tenaga kerja yang ada mayoritas bekerja di sektor barang yang menjadi unggulan untuk di ekspor ke amerika serikat.

\section{Pengaruh kurs, tenaga kerja dan Jumlah penduduk terhadap impor Indonesia dari Amerika Serikat}

\section{Hasil regresi}

Untuk mengetahui hasil regresi Kurs, Tenaga kerja dan Jumlah penduduk terhadap impor Indonesia dari Amerika Serikat dapat dilihat pada Tabel 5 berikut ini :

Tabel 5. Hasil regresi kurs, tenaga kerja dan jumlah penduduk terhadap impor Indonesia dari Amerika Serikat

\begin{tabular}{lrrrr}
\hline \multicolumn{1}{c}{ Variable } & Coefficient & Std. Error & t-Statistic & Prob. \\
\hline C & -17271.41 & 5510.222 & -3.134431 & 0.0048 \\
Kurs & -0.614256 & 0.121111 & -5.071861 & 0.0000 \\
Jumlah penduduk & -38.25993 & 93.50948 & -0.409156 & 0.6864 \\
TK & 0.336179 & 0.073105 & 4.598554 & 0.0001 \\
R-squared & 0.846601 & Mean dependent var & 5916.423 \\
Adjusted R-squared & 0.825683 & S.D. dependent var & 2817.100 \\
S.E. of regression & 1176.176 & Akaike info criterion & 17.11856 \\
Sum squared resid & 30434578 & Schwarz criterion & 17.31212 \\
Log likelihood & -218.5413 & Hannan-Quinn criter. & 17.17430 \\
F-statistic & 40.47227 & Durbin-Watson stat & 1.401406 \\
Prob(F-statistic) & 0.000000 & & \\
\hline Sumber: Datadiotah & & & \\
\end{tabular}

Sumber: Data diolah, 2021 


\section{Hasil uji asumsi klasik}

\section{Autokorelasi}

Untuk mengetahui hasil uji autokorelasi digunakan Uji LM tes dengan hasilnya sebagai berikut :

Tabel 6. Hasil uji autokorelasi

\begin{tabular}{llll}
\hline Breusch-Godfrey Serial Correlation LM Test: & \\
\hline F-statistic & 1.042085 & Prob. F(2,20) & 0.3711 \\
Obs*R-squared & 2.453723 & Prob. Chi-Square(2) & 0.2932 \\
\hline
\end{tabular}

Sumber : Data diolah, 2021

Berdasarkan hasil uji LM tes diperoleh kesimpulan nilai Probabilitas ObsRsquare nya sebesar 0,29 besar dari alpa 5\% sehingga disimpulkan bahwa tidak terdapat gejala Autokorelasi

\section{Heteroskedastis}

Untuk menguji ada tidaknya masalah heteroskedastis pada model digunakan uji LM Tes dengan hasil sebagai berikut :

Tabel 7. Hasil uji heteroskedastis

\begin{tabular}{lcll}
\hline Heteroskedasticity & Test: Breusch-Pagan-Godfrey & \\
\hline F-statistic & 0.526039 & Prob. F(3,22) & 0.6690 \\
Obs*R-squared & 1.740216 & Prob. Chi-Square(3) & 0.6280 \\
Scaled explained SS & 1.035752 & Prob. Chi-Square(3) & 0.7926 \\
\hline
\end{tabular}

Sumber : Data diolah, 2021

Berdasarkan hasil diatas terlihat bahwa nilai probabilitas Obsrsquare sebesar 0.62 besar dari alpha 5\% sehingga dapat disimpulkan tidak terdapat gejala heteroskedastis

\section{Multikolinearitas}

Untuk mengetahui adanya multikolieritas dengan melihat nilai VIF

Tabel 8. Hasil uji multikolinearitas

\begin{tabular}{cccc}
\hline Variable & $\begin{array}{c}\text { Coefficient } \\
\text { Variance }\end{array}$ & $\begin{array}{c}\text { Uncentered } \\
\text { VIF }\end{array}$ & $\begin{array}{c}\text { Centered } \\
\text { VIF }\end{array}$ \\
\hline C & 30362541 & 570.6461 & NA \\
Kurs & 0.014668 & 24.45031 & 3.416649 \\
Jumlah penduduk & 8744.022 & 2587.134 & 17.32706 \\
TK & 0.005344 & 1005.140 & 17.36616 \\
\hline
\end{tabular}

Sumber : Data diolah, 2021

Berdasarkan hasil diatas terlihat nilai VIF lebih dari 10 artinya memang terdapat gejala Multikolinearitas

\section{Hasil uji statistik}

\section{Uji F}

Berdasarkan nilai $\mathrm{F}$ hitung 40,4 dengan probabilitas mendekati nol maka disimpulkan secara bersama-sama variabel bebas Kurs,Jumlah penduduk dan tenaga kerja berpengaruh signifikan terhadap impor Indonesia dari amerika serikat. 


\section{Uji t}

Untuk menguji statistik secara parsial pengaruh masing-masing variabel kurs,jumlah tenaga kerja dan jumlah penduduk terhadap ekspor Indonesia ke Amerika Serikat digunakan uji t statistik dengan hasil sebagai berikut :

Variabel kurs Nilai t hitung -5,07 dengan probabilitas 0,000 kecil dari alpha 1\% artinya kurs berpengaruh signifikan terhadap impor Indonesia dari Amerika Serikat pada level $1 \%$

Variabel jumlah penduduk dengan nilai t hitung $-0,4$ dengan probailitas 0,69 besar dari alpha maksimal 10\% artinya secara parsial jumlah penduduk tidak berpengaruh signifikan terhadap impor Indonesia dari amerika serikat.

Variabel tenaga kerja dengan nilai t hitung 4,59 dengan probabilitas 0,0001 kecil dari alpha $1 \%$ sehingga disimpulkan tenaga kerja berpengaruh signifikan terhadap impor Indonesia dari amerika serikat.

\section{Koefisien determinasi}

Koefisien determinasi (R square) dengan nilai 0,84 artinya 84\% perubahan impor Indonesia dari Amerika Serikat dipengaruhi oleh variabel bebas dalam model sisanya $16 \%$ berada diluar model

\section{Interpretasi hasil regresi}

Berdasarkan hasil regresi diperoleh persamaan sebagai berikut :

\section{Impor dari Amerika Serikat = -17271-0,61Kurs-38,2JP+0,33TK+e}

Berdasarkan hasil uji signifikansi maka yang di interpretasikan dari hasil regresi yaitu: 1).Konstanta menunjukkan pada posisi semua variabel bebas bernilai nol maka nilai impor Indonesia dari Amerika Serikat -17271 Juta US Dolar. 2).Koefisien regresi kurs menunjukkan jika kurs meningkat atau terdeprisiasi 1 rupiah maka impor Indonesia ke Amerika Serikat dalam jangka panjang akan turun sebesar 0,61 juta us dolar. 3).Koefisien regresi Tenaga kerja 0,33 menunjukkan jika terjadi kenaikan Tenaga kerja sebesar 1 ribu jiwa maka impor Indonesia dari Amerika Serikat akan naik sebesar 0,33 juta us dollar, 4).Koefisien regresi Jumlah penduduk tidak berpengaruh signifikan terhadap ekspor Indonesia ke Amerika Serikat berdasarkan uji t

\section{Implikasi hasil}

Dari hasil penelitian menunjukkan kurs berpengaruh negatif signifikan hal ini sesuai secara teori karena jika kurs terdepresiasi maka impor akan turun, kenaikan nilai tukar dolar terhadap rupiah menyebabkan harga barang impor akan menjadi naik sehingga permintaan impor didalam negeri pun akan turun, dalam teori permintaan jika harga naik maka permintaan akan turun, kenaikan kurs menyebabkan harga barang amerika otomatis akan naik sehingga dengan naiknya harga barang amerika menyebabkan permintaan barang impor akan turun.

Hasil regresi lainnya variabel tenaga kerja menunjukkan pengaruh positif dan signifikan hal ini secara transmisi dapat dijelaskan jika tenaga kerja meningkat artinya terjadi peningkatan produksi, peningkatan output atau produksi membutuhkan barangbarang modal dari luar negeri hal inilah yang menyebabkan impor meningkat, sementara jumlah penduduk tidak berpengaruh signifikan terhadap impor artinya pergerakan atau fluktuasi jumlah penduduk tidak memiliki dampak dalam meningkatnya permintaan barang impor atau menurunnya barang impor. 


\section{Pengaruh kurs, tenaga kerja dan jumlah penduduk terhadap ekspor Indonesia ke China}

\section{Hasil regresi}

Untuk mengetahui pengaruh kurs,tenaga kerja dan jumlah penduduk terhadap ekspor Indonesia ke China dapat dilihat pada hasil regresi tabel berikut ini :

Tabel 9. Hasil regresi pengaruh kurs,tenaga kerja dan jumlah penduduk terhadap ekspor Indonesia ke China

\begin{tabular}{lrrrr}
\hline \multicolumn{1}{c}{ Variable } & Coefficient & Std. Error & t-Statistic & Prob. \\
\hline \multicolumn{1}{c}{ C } & -71732.93 & 11010.05 & -6.515225 & 0.0000 \\
Kurs & -0.945904 & 0.241993 & -3.908815 & 0.0008 \\
\multicolumn{1}{c}{ Jumlahpenduduk } & 194.8377 & 186.8425 & 1.042791 & 0.3084 \\
\multicolumn{1}{c}{ TK } & 0.661460 & 0.146073 & 4.528284 & 0.0002 \\
R-squared & 0.932930 & Mean dependent var & 9963.500 \\
Adjusted R-squared & 0.923784 & S.D. dependent var & 8512.744 \\
S.E. of regression & 2350.133 & Akaike info criterion & 18.50297 \\
Sum squared resid & $1.22 E+08$ & Schwarz criterion & 18.69652 \\
Log likelihood & -236.5386 & Hannan-Quinn criter. & 18.55871 \\
F-statistic & 102.0052 & Durbin-Watson stat & 1.391176 \\
Prob(F-statistic) & 0.000000 & & & \\
\hline Sumber: Data & & & &
\end{tabular}

Sumber: Data diolah, 2021

\section{Hasil uji asumsi klasik :}

\section{Autokorelasi}

Untuk mengetahui terdapat autokorelasi atau tidak digunakan ujia LM Test dengan hasilnya sebagai berikut :

Tabel 10. Hasil uji autokorelasi

\begin{tabular}{llll}
\hline \multicolumn{4}{l}{ Breusch-Godfrey Serial Correlation LM Test: } \\
\hline F-statistic & 1.641891 & Prob. F(2,20) & 0.2187 \\
Obs*R-squared & 3.666858 & Prob. Chi-Square(2) & 0.1599 \\
\hline
\end{tabular}

Sumber : Data diolah, 2021

Berdasarkan hasil tersebut terlihat bahwa nilai ObsRsquared 0,15 lebih besar dari alpha $5 \%$ sehingga disimpulkan tidak terdapat autokorelasi.

\section{Heteroskedastisitas}

Untuk mengetahui terdapat heteroskedastis dilakukan uji LM tes dengan hasilnya sebagai berikut :

Tabel 11. Hasil uji heteroskedastisitas

\begin{tabular}{|c|c|c|c|}
\hline \multicolumn{4}{|c|}{ Heteroskedasticity Test: Breusch-Pagan-Godfrey } \\
\hline F-statistic & 2.749413 & Prob. $F(3,22)$ & 0.0671 \\
\hline Obs*R-squared & 7.089809 & Prob. Chi-Square(3) & 0.0691 \\
\hline Scaled explained SS & 6.547446 & Prob. Chi-Square(3) & 0.0878 \\
\hline
\end{tabular}

Sumber : Data diolah, 2021

Berdasarkan hasil tersebut tidak terdapat gejala heteroskedastis nilai probabilitas ObsRsquare 0,069 besar dari alpha 5\% $(0,0050)$ 


\section{Multikolinearitas}

Untuk melihat ada tidaknya multikolinearitas dapat dilihat pada nilai VIF

Tabel 12. Hasil uji multikolinearitas

\begin{tabular}{cccc}
\hline \multirow{2}{*}{ Variable } & \multicolumn{2}{c}{ Coefficient } \\
Variance & VIF & VIF \\
\hline C & $1.21 E+08$ & 570.6461 & NA \\
KURS & 0.058560 & 24.45031 & 3.416649 \\
JUMLAHPENDUD & & & \\
UK & 34910.13 & 2587.134 & 17.32706 \\
TK & 0.021337 & 1005.140 & 17.36616 \\
\hline
\end{tabular}

Sumber : Data diolah, 2021

Berdasarkan dari data diatas terlihat nilai VIF besar dari 10 maka memang terdapat gejala multikolineritas

\section{Hasil uji statistik}

Uji F

Berdasarkan nilai $\mathrm{F}$ hitung 102 dengan probabilitas mendekati nol maka disimpulkan secara bersama-sama variabel bebas Kurs,Jumlah penduduk dan tenaga kerja berpengaruh signifikan terhadap ekspor Indonesia ke China

\section{Uji t}

Untuk menguji statistik secara parsial pengaruh masing-masing variabel kurs,jumlah tenaga kerja dan jumlah penduduk terhadap ekspor Indonesia ke China digunakan uji t statistik. Variabel kurs nilai t hitung -3,90 dengan probabilitas 0,0008 kecil dari alpha $1 \%$ artinya kurs berpengaruh signifikan terhadap ekspor Indonesia ke China pada level $1 \%$. Variabel jumlah penduduk dengan nilai t hitung 1,04 dengan probailitas 0,30 besar dari alpha minimal $10 \%$ artinya secara parsial jumlah penduduk tidak berpengaruh signifikan terhadap ekspor ke China. Variabel tenaga kerja dengan nilai $\mathrm{t}$ hitung 4,52 dengan probabilitas 0,0008 kecil dari alpha 1\% sehingga disimpulkan tenaga kerja berpengaruh signifikan terhadap ekspor ke China

\section{Koefisien determinasi}

Koefisien Determinasi (R square) dengan nilai 0,93 artinya 93\% perubahan ekspor Indonesia ke China dipengaruhi oleh variabel bebas dalam model sisanya $7 \%$ berada diluar model

\section{Interpretasi hasil regresi}

Berdasarkan hasil regresi diperoleh persamaan sebagai berikut :

\section{Ekspor ke China = -71732-0,94Kurs+194,8JP-0.66TK+e}

Berdasarkan hasil uji signifikansi maka yang di interpretasikan dari hasil regresi yaitu : 1).Konstanta menunjukkan pada posisi semua variabel bebas bernilai nol maka nilai ekspor Indonesia ke China -71622 Juta US Dolar. 2).Koefisien regresi kurs menunjukkan jika kurs meningkat atau terdeprisiasi 1 rupiah maka ekspor Indonesia ke China dalam jangka panjang akan turun sebesar 0,94 juta us dolar. 3).Koefisien jumlah penduduk tidak berpengaruh signifikan terhadap ekspor Indonesia ke China. 4).Koefisien 
regresi tenaga kerja 0,66 artinya jika terjadi kenaikan tenaga kerja sebanyak satu juta jiwa akan menyebabkan terjadinya kenaikan ekspor ke China sebesar 0,66 Juta us dollar

\section{Implikasi hasil}

Berdasarkan hasil regresi diperoleh hasil ternyata kurs berpengaruh negatif dan signifikan terhadap ekspor Indonesia ke China hal ini ternyata sama dengan pengaruhnya terhadap ekspor Indonesia ke Amerika Serikat pada uraian sebelumnya dan penjelasannya pun sama yakni secara teoritis dalam jangka pendek hal ini mungkin berbeda dengan kenyataan karena seharusnya dengan terdepresiasinya rupiah harusnya ekspor meningkat karena harga barang ekspor Indonesia jadi lebih murah namun asumsi ini terjadi hanya dalam jangka pendek karena jika dalam jangka panjang kurs terdepresiasi akan menyebabkan harga barang modal yang sering diimpor Indonesia akan lebih mahal hal ini akan meningkatkan biaya produksi dan menyebabkan turunnya produksi termasuk untuk ekspor karena penelitian ini periode penelitiannya dalam jangka panjang maka asumsi tersebut telah terpenuhi sesuai dengan penejelasan ekonomi yang telah diuraikan tersebut.

Sementara hasil regresi lainnya menunjukkan jumlah penduduk tidak berpengaruh signifikan terhadap ekspor Indonesia ke China hal ini menunjukkan bahwa fluktuasi penduduk tidak memiliki dampak terhadap ekspor Indonesia ke China dan hasil lainnya menunjukkan tenaga kerja ternyata berpengaruh positif signifikan dalam mempengaruhi ekspor Indonesia ke China hal ini mengindikasikan tenaga kerja yang ada mayoritas bekerja di sektor barang yang menjadi unggulan untuk di ekspor ke China.

\section{Pengaruh kurs, tenaga kerja dan Jumlah penduduk terhadap impor Indonesia dari China}

Untuk mengetahui hasil regresi Kurs, Tenaga kerja dan Jumlah penduduk terhadap impor Indonesia dari China dapat dilihat pada tabel berikut ini :

Tabel 13. Hasil regresi Jumlah penduduk terhadap impor Indonesia dari China kurs, tenaga kerja dan

\begin{tabular}{lrccr}
\hline \multicolumn{1}{c}{ Variable } & Coefficient & Std. Error & t-Statistic & Prob. \\
\hline \multicolumn{1}{c}{ C } & -108474.7 & 14647.33 & -7.405761 & 0.0000 \\
KURS & -1.303888 & 0.321937 & -4.050129 & 0.0005 \\
JUMLAHPENDUDUK & 107.5757 & 248.5680 & 0.432782 & 0.6694 \\
\multicolumn{1}{c}{ TK } & 1.209088 & 0.194330 & 6.221835 & 0.0000 \\
R-squared & 0.955783 & Mean dependent var & 13489.04 \\
Adjusted R-squared & 0.949753 & S.D. dependent var & 13947.88 \\
S.E. of regression & 3126.524 & Akaike info criterion & 19.07387 \\
Sum squared resid & $2.15 E+08$ & Schwarz criterion & 19.26742 \\
Log likelihood & -243.9603 & Hannan-Quinn criter. & 19.12961 \\
F-statistic & 158.5152 & Durbin-Watson stat & 1.220276 \\
Prob(F-statistic) & 0.000000 & & \\
\hline Sumber : Data & & &
\end{tabular}

Sumber : Data diolah, 2021

\section{Hasil uji asumsi klasik}

\section{Autokorelasi}

Untuk mengetahui hasil uji autokorelasi digunakan Uji LM tes dengan hasilnya sebagai berikut : 
Tabel 12. Hasil uji autokorelasi

\begin{tabular}{lcll}
\hline Breusch-Godfrey Serial Correlation LM Test: & \\
\hline F-statistic & 0.725140 & Prob. F(2,20) & 0.4966 \\
Obs*R-squared & 1.757891 & Prob. Chi-Square(2) & 0.4152 \\
\hline
\end{tabular}

Sumber : Data diolah, 2021

Berdasarkan hasil uji L M tes diperoleh kesimpulan nilai Probabilitas ObsRsquare nya sebesar 0,41 besar dari alpa 5\% sehingga disimpulkan bahwa tidak terdapat gejala Autokorelasi

\section{Heteroskedastis}

Untuk menguji ada tidaknya masalah heteroskedastis pada model digunakan uji LM Tes dengan hasil sebagai berikut :

Tabel 12. Hasil uji heteroskedastis

\begin{tabular}{lcll}
\hline Heteroskedasticity Test: Breusch-Pagan-Godfrey & \\
\hline F-statistic & 0.825535 & Prob. F(3,22) & 0.4939 \\
Obs*R-squared & 2.630747 & Prob. Chi-Square(3) & 0.4521 \\
Scaled explained SS & 2.085631 & Prob. Chi-Square(3) & 0.5548 \\
\hline
\end{tabular}

Sumber : Eviews

Berdasarkan hasil diatas terlihat bahwa nilai probabilitas Obsrsquare sebesar 0.45 besar dari alpha 5\% sehingga dapat disimpulkan tidak terdapat gejala heteroskedastis

\section{Multikolinearitas}

Untuk mengetahui adanya multikolieritas dengan melihat nilai VIF

Tabel 13. Hasil uji Multikolinearitas

\begin{tabular}{cccc}
\hline Variable & $\begin{array}{c}\text { Coefficient } \\
\text { Variance }\end{array}$ & $\begin{array}{c}\text { Uncentered } \\
\text { VIF }\end{array}$ & $\begin{array}{c}\text { Centered } \\
\text { VIF }\end{array}$ \\
\hline C & $2.15 E+08$ & 570.6461 & NA \\
Kurs & 0.103644 & 24.45031 & 3.416649 \\
Jumlahpenduduk & 61786.03 & 2587.134 & 17.32706 \\
TK & 0.037764 & 1005.140 & 17.36616 \\
\hline
\end{tabular}

Sumber : Data diolah, 2020

Berdasarkan hasil diatas terlihat nilai VIF lebih dari 10 artinya memang terdapat gejala Multikolinearitas

\section{Hasil uji statistik}

Uji F

Berdasarkan nilai $\mathrm{F}$ hitung 158 dengan probabilitas mendekati nol maka disimpulkan secara bersama-sama variabel bebas Kurs,Jumlah penduduk dan tenaga kerja berpengaruh signifikan terhadap impor Indonesia dari China

\section{Uji t}

Untuk menguji statistik secara parsial pengaruh masing-masing variabel kurs,jumlah tenaga kerja dan jumlah penduduk terhadap ekspor Indonesia ke Amerika Serikat digunakan uji t statistik dengan hasil sebagai berikut : 
Variabel kurs nilai t hitung $-4,05$ dengan probabilitas 0,0005 kecil dari alpha $1 \%$ artinya kurs berpengaruh signifikan terhadap impor Indonesia dari China pada level 1\%

Variabel jumlah penduduk dengan nilai t hitung 0,43 dengan probailitas 0,66 besar dari alpha maksimal 10\% artinya secara parsial jumlah penduduk tidak berpengaruh signifikan terhadap impor Indonesia dari China.

Variabel tenaga kerja dengan nilai t hitung 6,22 dengan probabilitas mendekati nol kecil dari alpha $1 \%$ sehingga disimpulkan tenaga kerja berpengaruh signifikan terhadap impor Indonesia dari China.

Koefisien Determinasi (R square) dengan nilai 0,95 artinya 95\% perubahan impor Indonesia dari China dipengaruhi oleh variabel bebas dalam model sisanya $5 \%$ berada diluar model

\section{Interpretasi hasil regresi}

\section{Berdasarkan hasil regresi diperoleh persamaan sebagai berikut :}

Berdasarkan hasil uji signifikansi maka yang di interpretasikan dari hasil regresi yaitu : 1).Konstanta menunjukkan pada posisi semua variabel bebas bernilai nol maka nilai impor Indonesia dari Amerika Serikat -108474 Juta US Dolar, 2).Koefisien regresi kurs menunjukkan jika kurs meningkat atau terdeprisiasi 1 rupiah maka impor Indonesia ke Amerika Serikat dalam jangka panjang akan turun sebesar 1,30 juta us dolar, 3).Koefisien regresi Tenaga kerja 1,20 menunjukkan jika terjadi kenaikan Tenaga kerja sebesar 1 ribu jiwa maka impor Indonesia dari Amerika Serikat akan naik sebesar 1,20 juta us dollar, 4).Koefisien regresi Jumlah penduduk tidak berpengaruh signifikan terhadap ekspor Indonesia ke Amerika Serikat berdasarkan uji t

\section{Impor dari Amerika Serikat = -108474-1,30Kurs+107JP+1,20TK+e}

\section{Implikasi hasil}

Dari hasil penelitian menunjukkan kurs berpengaruh negatif signifikan hal ini mirip dengan hasil pengaruh kurs terhadap impor Indonesia ke Amerika Serikat pada uraian sebelumnya yang sesuai secara teori karena jika kurs terdepresiasi maka impor akan turun, kenaikan nilai tukar dolar terhadap rupiah menyebabkan harga barang impor akan menjadi naik sehingga permintaan impor didalam negeri pun akan turun, dalam teori permintaan jika harga naik maka permintaan akan turun, kenaikan kurs menyebabkan harga barang China otomatis akan naik sehingga dengan naiknya harga barang China menyebabkan permintaan barang impor dari China akan turun.

Hasil regresi lainnya variabel tenaga kerja menunjukkan pengaruh positif dan signifikan hal ini juga sama dengan hasil pengaruh tenaga kerja terhadap impor Indonesia dari Amerika Serikat secara transmisi dapat dijelaskan jika tenaga kerja meningkat artinya terjadi peningkatan produksi, peningkatan output atau produksi membutuhkan barang-barang modal dari luar negeri hal inilah yang menyebabkan impor meningkat, sementara jumlah penduduk tidak berpengaruh signifikan terhadap impor artinya pergerakan atau fluktuasi jumlah penduduk tidak memiliki dampak dalam meningkatnya permintaan barang impor atau menurunnya barang impor.

\section{KESIMPULAN DAN SARAN}

\section{Kesimpulan}

Rata-rata perbandingan ekspor Indonesia ke Amerika Serikat dan ekspor Indonesia ke China adalah 2,02 sementara rata-rata perbandingan Impor Indonesia dari Amerika Serikat dan impor Indonesia dari China adalah 1,31 sehinga kesimpulannya ekspor dan 
impor Indonesia dengan Amerika Serikat secara rata-rata lebih besar jika dibandingkan dengan ekspor dan impor Indonesia dengan China.

Berdasarkan hasil regresi Variabel kurs berpengaruh negatif signifikan terhadap ekspor dan impor Indonesia dengan Amerika Serikat dan China, Variabel tenaga kerja berpengaruh positif dan signifikan terhadap ekspor Indonesia ke Amerika Serikat dan China dan berpengaruh positif signifikan terhadap impor Indonesia dari Amerika Serikat dan China, sementara variabel jumlah penduduk berpengaruh positif signifikan terhadap ekspor Indonesia ke Amerika Serikat dan tidak berpengaruh signifikan terhadap impor Indonesia dari Amerika Serikat serta ekspor dan impor Indonesia dengan China.

\section{Saran}

Kecendrungan perdagangan Indonesia beberapa tahun terakhir meningkat dengan China dan sendrung menurun ke amerika namun dari Rata-rata perdagangan Indonesia yang lebih besar ke Amerika Serikat dibandingkan ke China dari tahun-tahun sebelumnya menunjukkan perlunya Indonesia meningkatkan daya saing dan hubungan dagang dengan amerika karena walaupun perdagangan ke China meningkat namun tidak menurunkan perdagangan Indonesia ke Amerika Serikat terutama ekspor. Sehingga ekspor dan rasio perdagangan di kedua negara tersebut sama-sama meningkat.

Kurs atau nilai tukar menunjukkan pengaruh negatif signifikan baik terhadap perdagangan dengan Amerika Serikat maupun dengan China dengan demikian pengendalian kurs atau nilai tukar merupakan hal yang sangat penting agar perdagangan dapat berjalan stabil dan tidak mengalami goncangan akibat kurs yang tidak stabil atau berfluktuasi terlalu tinggi atau terlalu rendah.

\section{DAFTAR PUSTAKA}

Asian Development Bank.(2018). Key indicators for Asia and Pasific 2017-2018. Asian Development Bank Statistics.

Darman, Darman. (2016). Analisis ekspor-impor dan indeks harga konsumen pada pertumbuhan ekonomi Indonesia. Jurnal Manajemen Indonesia, 16(1), 39-50

Dornbusch, Rudiger, Stanley Fischer, Richard Startz.(2004). Macroeconomics. 9th Edition. McGraww-Hill: New York

Fatmawati. (2015). Analisis pengaruh perdagangan luar negeri dan hutang terhadap PDB.Jurnal JESP.Universitas Negeri Malang: Malang

Gaspersz, Vincent. (1997). Manajemen kualitas penerapan konsep-konsep kualitas dalam manajemen bisnis total. PT. Gramedia Pustaka Utama: Jakarta.

Gujarati, Damodar N. (2003). Basic econometrics. Fourth edition, International Edition. MC Grow Hill: New York

Gujarati, Damodar N.(2004). Basic econometrics. 4th Edition. McGraw-Hill: New York Haryadi. (2007). Ekonomi internasional teori dan kebijakan. Biografika: Bogor

Kuswantoro dan Gita Rosianawati. (2016). Analisis pengaruh PDB riil,Cadangan devisa dan Nilai tukar rupiah terhadap impor non migas Indonesia, Jurnal Ekonomi Qu (Jurnal Ilmu Ekonomi), 6(2), 166-190

Mankiw, George N. (2001). Macroeconomics. 5th Edition. McGraw-Hill: New York

Nopirin. (2003). Ekonomi Intrenasional, BPFE UGM: Yogyakarta

Pradnyani dkk. (2018). Pengaruh variabel makro ekonomi terhadap penyaluran ekspor impor dengan metode pembayaran letter of credit. Journal of Agribusiness and Rural Development Research. 4(1), 44-50

Sims, Christoper. (1980). Macroeconomics and reality. Econometrica. 48(1), 1-48 (48 
Yeti Andriani, Andre. (2017). Implikasi perjanjian kemitraan ekonomi komprehensif Indonesia Australia terhadap perdagangan luar negeri. Andalas Journal of International Studies, 6(1), 79-92

Yusuf, dan Widyastutik. 2007. Analisis pengaruh ekspor-impor komoditas pangan utama dan liberalisasi perdagangan terhadap neraca perdagangan Indonesia.Jurnal Manajemen Agribisnis Fakultas Ekonomi dan Manajemen, IPB. 4(1), 46-56s 